\title{
Extracellular protease-producing actinomycetes and other bacteria in cultivated soil
}

\author{
RAINA NISKANEN ${ }^{1}$ and EVA EKLUND ${ }^{2}$ \\ ${ }^{1}$ Department of Agricultural Chemistry, University of Helsinki, \\ SF-00710 HELSINKI, Finland \\ ${ }^{2}$ Department of Microbiology, University of Helsinki, \\ SF-00710 HELSINKI, Finland
}

\begin{abstract}
The occurrence and properties of extracellular protease-producing actinomycetes and other bacteria in cultivated soil were studied. Experimental soils consisted of three mineral soil samples and one Sphagnum peat sample from a greenhouse. The mineral soil samples represented arable, pasture and uncultivated soils.

From experimental soils, 240 bacterial strains were isolated, 68 strains thereof were proteolytic. A greater number of proteolytic strains originated from pasture soil than from the other soils. Actinomycetes accounted for $70 \%$ of the proteolytic strains isolated from pasture soil. Several proteolytic bacteria were isolated also from peat, but only few of them were typical actinomycetes. Many strains with high extracellular protease activity proved to be fermentative bacilli.

Production of oxidase enzymes, significant in the humification processes, occurred frequently among strains isolated from pasture soil and peat. The ability to produce dark melanoid pigments was a frequently noted characteristic of the proteolytic actinomycetes.
\end{abstract}

Index words: soil proteases, soil phenoloxidases, soil oxidases, humus polymerization

\section{Introduction}

Transformation of organic matter in soil is partially catalyzed by enzymes found outside the living soil organisms (SKUנINS 1967). Many soil microorganisms release extracellular enzymes into the soil, and these enzymes are involved in the decomposition of plant, animal and microbial residues. Proteases are enzymes which hydrolyze residues containing peptide bonds. Energy and nutrients are formed in the degradation process of organic residues, and the degradation products are also involved in the formation of humic matter.

Soil is a very complicated environment and enzymes acting therein are supposed to tolerate numerous environmental factors. However, it is well known that part of the enzymes remain 
in the soil in an active state for a certain period (SKUJINŠ 1967). The persistence of extracellular proteases in soil is enhanced by their adsorption to soil organic matter and clay particles. Ionically bound proteases might represent readily mobilizable reserves, while covalently bound proteases form a more stable but immobilized reserve (LADD 1972).

The composition and abundance of soil microbial flora producing extracellular proteases are affected by environmental factors such as moisture, temperature, aeration, acidity and type and content of organic matter. These factors are remarkably affected by cultivation. In arable soil, various measures related to cultivation bring about considerable fluctuations in environmental conditions. In view of soil microbes, regularly repeated ploughing is a radical action, while in pasture soil which is not tilled every year, undisturbed development of microbial flora may continue. When decomposable organic residues occur in abundance in soil, microbial flora proliferates in the presence of favourable environmental conditions. In this respect, excess acidity is a usual limiting factor. Well humified soil organic matter is not primarily important as a source of energy, but it has favourable effects on the environment, e.g. increasing the waterholding capacity of the soil.

The aim of this study was to investigate the occurrence and properties of extracellular protease-producing actinomycetes and other bacteria in cultivated soil.

\section{Material and methods}

Experimental soils. For isolation of proteolytic soil organisms, four soil samples were collected. Three of the samples representing arable, pasture and uncultivated soil were from the surface layer of mineral soils and one sample was a Sphagnum peat sample from a greenhouse. The $\mathrm{pH}$ of the soil was measured in a soil $-0.01 \mathrm{M} \mathrm{CaCl}_{2}$ suspension $(1: 2.5)$ (RYTI 1965). The organic carbon content of the samples was determined using a modification (Graham 1948) of Alten's wet combustion method. The samples, by increasing $\mathrm{pH}$, were as follows:

$\begin{array}{ll}\text { Sample No. } & \text { Origin } \\ 1 & \text { Uncultivated soil } \\ 2 & \text { Arable soil } \\ 3 & \text { Greenhouse peat } \\ 4 & \text { Pasture soil }\end{array}$

$\begin{array}{lcc}\text { Soil class } & \mathrm{pH} & \text { Org.C, } \% \\ \text { Muddy clay } & 3.5 & 3.1 \\ \text { Coarser finesand } & 5.0 & 3.1 \\ \text { Sphagnum peat } & 5.7 & 43.4 \\ \text { Coarser finesand } & 6.0 & 4.9\end{array}$

Isolation of soil organisms. Samples of $5 \mathrm{~g}$ undried soil were dispersed in $100 \mathrm{ml}$ of sterilized phosphate buffer solution ( $\mathrm{pH}$ 7.2) using a sterile Ultra Turrax K homogenizer. Three successive hundredfold dilutions of soil suspensions were prepared with sterilized phosphate buffer solution, shaken by hand, and five replicates of $1 \mathrm{ml}$ and $0.1 \mathrm{ml}$ of the two latter dilutions were plated in the following medium: soluble starch, Bacto peptone and yeast extract $0.5 \mathrm{~g}$ each, glycerol $1 \mathrm{ml}$, $\mathrm{K}_{2} \mathrm{HPO}_{4} 0.2 \mathrm{~g}, \mathrm{MgSO}_{4} .7 \mathrm{H}_{2} \mathrm{O} 0.05 \mathrm{~g}, 0.01 \%$ $\mathrm{FeCl}_{3}$ water solution 4 drops, agar $15 \mathrm{~g}$, soil extract $250 \mathrm{ml}$, distilled water $750 \mathrm{ml}$, actidione $20 \mathrm{mg}, \mathrm{pH} 6.9$. The medium was distributed in $10 \mathrm{ml}$ portions into test tubes and sterilized at $120^{\circ} \mathrm{C}$ for 20 minutes. Ten grams of milk powder was dissolved in $100 \mathrm{ml}$ distilled water and sterilized at $118^{\circ} \mathrm{C}$ for 15 min. and supplied into the medium (10\% $\mathrm{v} / \mathrm{v})$. The plates were incubated at room temperature for one week and counted after two and six days. The criterion of identification of caseolytic organisms was a clear zone surrounding the colony. For isolation of actinomycetes, five replicates of $1 \mathrm{ml}$ of the three dilutions were plated in chitine agar (SKERMAN 1969). The plates were incubated at room temperature for one week and counted after incubation.

Testing of physiological characteristics. Proteolytic and chitinolytic colonies were transferred to test tubes containing $2.5 \mathrm{ml}$ semisolid medium (7 g agar per $1000 \mathrm{ml}$ ) 
which was prepared in the same way as the medium for isolation of soil organisms except that it contained no actidione. The cultures were incubated at room temperature until good growth was found. Thereafter the strains were transferred to liquid media: tryptone and yeast extract $0.5 \mathrm{~g}$ each, $\mathrm{KH}_{2} \mathrm{PO}_{4} 0.4 \mathrm{~g}$, $\mathrm{MgSO}_{4} \cdot 7 \mathrm{H}_{2} \mathrm{O} 0.05 \mathrm{~g}, \mathrm{NaCl} 0.1 \mathrm{~g}, \mathrm{FeCl}_{3} 0.01 \mathrm{~g}$, soil extract $250 \mathrm{ml}$, distilled water $750 \mathrm{ml}$, $\mathrm{pH} 6.8$, sterilized at $120^{\circ} \mathrm{C}$ for $20 \mathrm{~min}$. The cultures were incubated at $28^{\circ} \mathrm{C}$ until good growth was found and then the strains were transferred with a multipoint inoculator to the media used for testing physiological characteristics.

The ability to denitrify was indicated by gas bubbles in the test tubes containing the liquid medium described above supplied with $7 \mathrm{~g}$ agar and $1 \mathrm{~g} \mathrm{KNO}_{3}$ per $1000 \mathrm{ml}$ and closed with vaspar. The utilization of glucose was tested with OF-medium (HugH and LEIFSON 1953). The oxidase activity was indicated by red colour brought about by $0.5 \%(\mathrm{w} / \mathrm{v})$ water solution of dimethyl-p-phenylendiaminehydrochloride (KLINGE 1960) in liquid medium cultures containing tryptone and yeast extract $5 \mathrm{~g}$ each and agar $7 \mathrm{~g}$ per $1000 \mathrm{ml}$. The production of melanine was noted in this medium. The proteolytic properties of the strains were tested with litmus milk: $20 \mathrm{ml} 2 \%$ solution of litmus, $1000 \mathrm{ml}$ skimmed milk, sterilized at $114^{\circ} \mathrm{C}$ for $15 \mathrm{~min}$. All tests were checked after one week of incubation at room temperature. After five days of incubation, growth was checked in three successive passages in synthetic medium with citrate as the sole carbon source (EKLUND 1970).

Determination of protease activity. Proteolytic strains were transferred to slants: tryptone $5 \mathrm{~g}$, glycerol $1 \mathrm{ml}$, yeast extract $0.5 \mathrm{~g}$, $\mathrm{KH}_{2} \mathrm{PO}_{4} 0.2 \mathrm{~g}, \mathrm{MgSO}_{4} \cdot 7 \mathrm{H}_{2} \mathrm{O} 0.05 \mathrm{~g}, \mathrm{FeCl}_{3}$ $0.01 \%$ water solution 4 drops, agar $15 \mathrm{~g}$, distilled water $1000 \mathrm{ml}, \mathrm{pH} 6.9$, sterilized at $121^{\circ} \mathrm{C}$ for $15 \mathrm{~min}$. The ability of strains to utilize casein was retested, and the strains showing good proteolysis were chosen for protease production. For cultivation of inoculum, strains were transferred to test tubes contain- ing $2 \mathrm{ml}$ of yeast extract-malt extract liquid medium (PridHAM et al. 1956-1957, ref. Shirling and Gottlieb 1966) and incubated for two days. Inocula were transferred to 250 $\mathrm{ml}$ conical flasks containing a medium presented by EKLUND et al. (1971) and shaken at $28^{\circ} \mathrm{C}(200 \mathrm{rpm})$. Samples for the determination of protease activity were taken after 3 , 4 and 5 days of incubation.

Protease activity was determined according to EKLUND et al. (1971). The growth solutions were allowed to hydrolyze casein at $40^{\circ} \mathrm{C}$ and $\mathrm{pH}$ 8.0. The reaction time was $20 \mathrm{~min}$ for the samples incubated for three days and $10 \mathrm{~min}$ for the samples incubated for four or five days. The reaction was stopped by precipitating the unhydrolyzed casein with $5 \%$ trichloroacetic acid. The content of tyrosine produced in casein hydrolysis was determined in the filtrates by measuring the absorbances of the assayed solutions and blanks at the wavelenght $280 \mathrm{~nm}$, using a Beckman DB spectrophotometer. One enzyme unit (EU) is the amount of enzyme which releases hydrolysis products at a rate equivalent to $1 \mathrm{meq}$ of tyrosine per minute under the conditions specified (JöNSSON 1969).

\section{Results}

The number of soil organisms grown on soil extract-milk agar plates are given in Table 1.

Table 1. Number of proteolytic and other soil organisms.

\begin{tabular}{|c|c|c|c|}
\hline \multirow[t]{2}{*}{$\frac{\text { Soil sample }}{\text { No. Origin }}$} & \multirow[t]{2}{*}{ Organism } & \multicolumn{2}{|c|}{$\begin{array}{c}\text { Number of organisms } \\
\left(\mathrm{g}^{-1} \text { of soil }\right) \times 10^{6}\end{array}$} \\
\hline & & $\begin{array}{c}\text { After } \\
2 \text { days of } \\
\text { incubation }\end{array}$ & $\begin{array}{l}\text { After } \\
6 \text { days of } \\
\text { incubation }\end{array}$ \\
\hline $\begin{array}{l}1 \text { Uncultivated } \\
\text { soil }\end{array}$ & $\begin{array}{l}\text { Proteolytic } \\
\text { Total }\end{array}$ & - & $\begin{array}{l}0.48 \\
0.56\end{array}$ \\
\hline 2 Arable soil & $\begin{array}{l}\text { Proteolytic } \\
\text { Total }\end{array}$ & - & $\begin{array}{l}0.16 \\
0.88\end{array}$ \\
\hline $\begin{array}{l}3 \text { Greenhouse } \\
\text { peat }\end{array}$ & $\begin{array}{l}\text { Proteolytic } \\
\text { Total }\end{array}$ & $\begin{array}{l}3.76 \\
7.76\end{array}$ & $\begin{array}{r}30.0 \\
115.5\end{array}$ \\
\hline 4 Pasture soil & $\begin{array}{l}\text { Proteolytic } \\
\text { Total }\end{array}$ & $\begin{array}{l}1.44 \\
9.24\end{array}$ & $\begin{array}{r}48.0 \\
143.6\end{array}$ \\
\hline
\end{tabular}


After two days of incubation, growth was found only among the organisms isolated from greenhouse peat and pasture soil. Nearly $50 \%$ of the colonies derived from peat and $16 \%$ of those derived from pasture soil were proteolytic. After six days of incubation, the percentages of proteolytic colonies isolated from these soil samples were 26 and 33, respectively. After six days of incubation, growth was found also on plates representing other soil samples, but the numbers of colonies were much smaller. The percentages of proteolytic colonies isolated from uncultivated and arable soil samples were 86 and 18 , respectively.

After seven days of incubation, growth was found on all chitine agar plates (Table 2). The

Table 2. Number of actinomycetes and other soil organisms counted on chitine agar plates.

\begin{tabular}{ccc}
\hline Soil sample & Organism & $\begin{array}{c}\text { Number of } \\
\text { organisms } \\
\left(\mathrm{g}^{-1} \text { soil }\right) \times 10^{6} \\
\text { after } 7 \text { days } \\
\text { of incubation }\end{array}$ \\
\hline
\end{tabular}

\begin{tabular}{llc}
\hline 1 Uncultivated & $\begin{array}{l}\text { Typical } \\
\text { soil }\end{array}$ & $\begin{array}{l}\text { actinomycetes } \\
\text { Total }\end{array}$ \\
2 Arable soil & $\begin{array}{l}\text { Typical } \\
\text { actinomycetes }\end{array}$ & 0.035 \\
& $\begin{array}{l}\text { Typical } \\
\text { actinomycetes }\end{array}$ & -54 \\
& $\begin{array}{l}\text { Other* } \\
\text { Peat }\end{array}$ & 3.50 \\
& $\begin{array}{l}\text { Typical } \\
\text { actinomycetes }\end{array}$ & 13 \\
\hline
\end{tabular}

* mainly nocardioforms and mycobacteria colonies grown on plates representing peat and pasture soil were more numerous than those representing other soil samples. All the colonies isolated from arable and pasture soil samples and $64 \%$ of those from the uncultivated soil sample were actinomycetes, while typical actinomycete colonies were not found on plates representing peat. However, the bacteria grown on these plates included Nocardia and Mycobacterium strains.

The number of bacterial strains isolated from soil extract-milk agar plates was 124 . The majority of the strains originated from peat and pasture soil samples (Table 3). Actinomycetes were isolated mainly from pasture soil. On the basis of physiological tests, proteolytic strains were isolated from all soils, but oxidase-producing and denitrifying strains only from peat and pasture soil (Table 3 ). The ability to produce melanine was associated exclusively with strains originating from pasture soil. The glucose utilization was mainly fermentative among strains originating from uncultivated and arable soil samples, but mainly oxidative among strains originating from peat. Strains originating from peat exhibited the poorest ability to grow in synthetic medium.

The number of strains isolated from chitine agar was 116. The proportion of actinomycetes was greatest among strains originating from pasture soil and lowest among those originating from peat (Table 4). Proteolytic and oxidase-producing strains originated more fre-

Table 3. Properties of all strains isolated from soil extract-milk agar plates.

\begin{tabular}{|c|c|c|c|c|}
\hline & \multicolumn{4}{|c|}{ Soil sample } \\
\hline & $\begin{array}{c}1 \\
\text { Uncultivated }\end{array}$ & $\begin{array}{c}2 \\
\text { Arable }\end{array}$ & $\begin{array}{c}3 \\
\text { Peat }\end{array}$ & $\begin{array}{c}4 \\
\text { Pasture }\end{array}$ \\
\hline Number of strains & \multicolumn{4}{|c|}{$\%$ of isolated strains } \\
\hline Typical actinomycetes & - & - & - & 26 \\
\hline Proteolytic & 33 & 67 & 15 & 23 \\
\hline Oxidase-producing & - & - & 72 & 56 \\
\hline Melanine-producing & - & - & - & 12 \\
\hline Fermentative glucose utilization & 66 & 67 & 5 & 26 \\
\hline Oxidative $\quad n$ & 17 & 33 & 72 & 32 \\
\hline Growth in synthetic medium & 67 & 100 & 40 & 58 \\
\hline Denitrifying & - & - & 5 & 6 \\
\hline
\end{tabular}


quently from peat and pasture soil than from the other soil samples. Melanine-producing strains were isolated from all soil samples. The majority of strains were able to grow without organic nitrogen, while the proportion of denitrifying strains was low. Oxidative utilization of glucose was more common than fermentative utilization.
The number of proteolytic strains was 68 , 30 of which were isolated from soil extractmilk agar plates (Table 5) and 38 from chitine agar plates (Table 6). The majority of proteolytic strains originated from pasture soil, actinomycetes accounting for $70 \%$.

The protease activity of 30 strains showing good proteolysis was determined (Fig. 1). Of

Table 4. Properties of strains isolated from chitine agar.

\begin{tabular}{|c|c|c|c|c|}
\hline & \multicolumn{4}{|c|}{ Soil sample } \\
\hline$y^{\prime}$ & $\begin{array}{c}1 \\
\text { Uncultivated }\end{array}$ & $\begin{array}{c}2 \\
\text { Arable }\end{array}$ & $\begin{array}{c}3 \\
\text { Peat }\end{array}$ & $\begin{array}{c}4 \\
\text { Pasture }\end{array}$ \\
\hline Number of strains & \multicolumn{4}{|c|}{$\%$ of isolated strains } \\
\hline Typical actinomycetes & 47 & 50 & 23 & 74 \\
\hline Proteolytic & 13 & 19 & 54 & 50 \\
\hline Oxidase-producing & 9 & 19 & 46 & 33 \\
\hline Melanine-producing & 13 & 31 & 8 & 30 \\
\hline Fermentative glucose utilization & 64 & 6 & 8 & 26 \\
\hline Oxidative $" \quad "$ & 7 & 75 & 92 & 41 \\
\hline Growth in synthetic medium & 76 & 63 & 85 & 67 \\
\hline Denitrifying & 7 & 6 & 8 & - \\
\hline
\end{tabular}

Table 5. Properties of proteolytic strains isolated from soil extract-milk agar plates.

\begin{tabular}{|c|c|c|c|c|}
\hline & \multicolumn{4}{|c|}{ Soil sample } \\
\hline , & $\begin{array}{c}1 \\
\text { Uncultivated }\end{array}$ & $\begin{array}{c}2 \\
\text { Arable }\end{array}$ & $\begin{array}{c}3 \\
\text { Peat }\end{array}$ & $\begin{array}{c}4 \\
\text { Pasture }\end{array}$ \\
\hline \multirow[t]{2}{*}{ Number of strains } & 2 & 4 & 8 & 16 \\
\hline & \multicolumn{4}{|c|}{$\%$ of isolated strains } \\
\hline Typical actinomycetes & - & - & - & 63 \\
\hline Oxidase-producing & - & - & 75 & 25 \\
\hline Melanine-producing & - & - & - & 31 \\
\hline Fermentative glucose utilization & 100 & 75 & 25 & 31 \\
\hline Oxidative $n$ & - & 25 & 63 & 50 \\
\hline Growth in synthetic medium & 100 & 100 & 50 & 88 \\
\hline Denitrifying & - & - & - & 6 \\
\hline
\end{tabular}

Table 6. Properties of proteolytic strains isolated from chitine agar.

\begin{tabular}{|c|c|c|c|c|}
\hline \multirow[t]{2}{*}{. } & \multicolumn{4}{|c|}{ Soil sample } \\
\hline & $\begin{array}{c}1 \\
\text { Uncultivated }\end{array}$ & $\begin{array}{c}2 \\
\text { Arable }\end{array}$ & $\begin{array}{c}3 \\
\text { Peat }\end{array}$ & $\begin{array}{c}4 \\
\text { Pasture }\end{array}$ \\
\hline \multirow[t]{2}{*}{ Number of strains } & 7 & 3 & 7 & 21 \\
\hline & \multicolumn{4}{|c|}{$\%$ of isolated strains } \\
\hline Typical actinomycetes & 43 & - & 14 & 76 \\
\hline Oxidase-producing & - & 33 & 43 & 24 \\
\hline Melanine-producing & 43 & - & - & 48 \\
\hline Fermentative glucose utilization & 43 & - & 14 & 14 \\
\hline Oxidative $" n$ & 29 & 100 & 86 & 67 \\
\hline Growth in synthetic medium & 57 & 100 & 86 & 81 \\
\hline Denitrifying & 14 & 33 & 14 & - \\
\hline
\end{tabular}



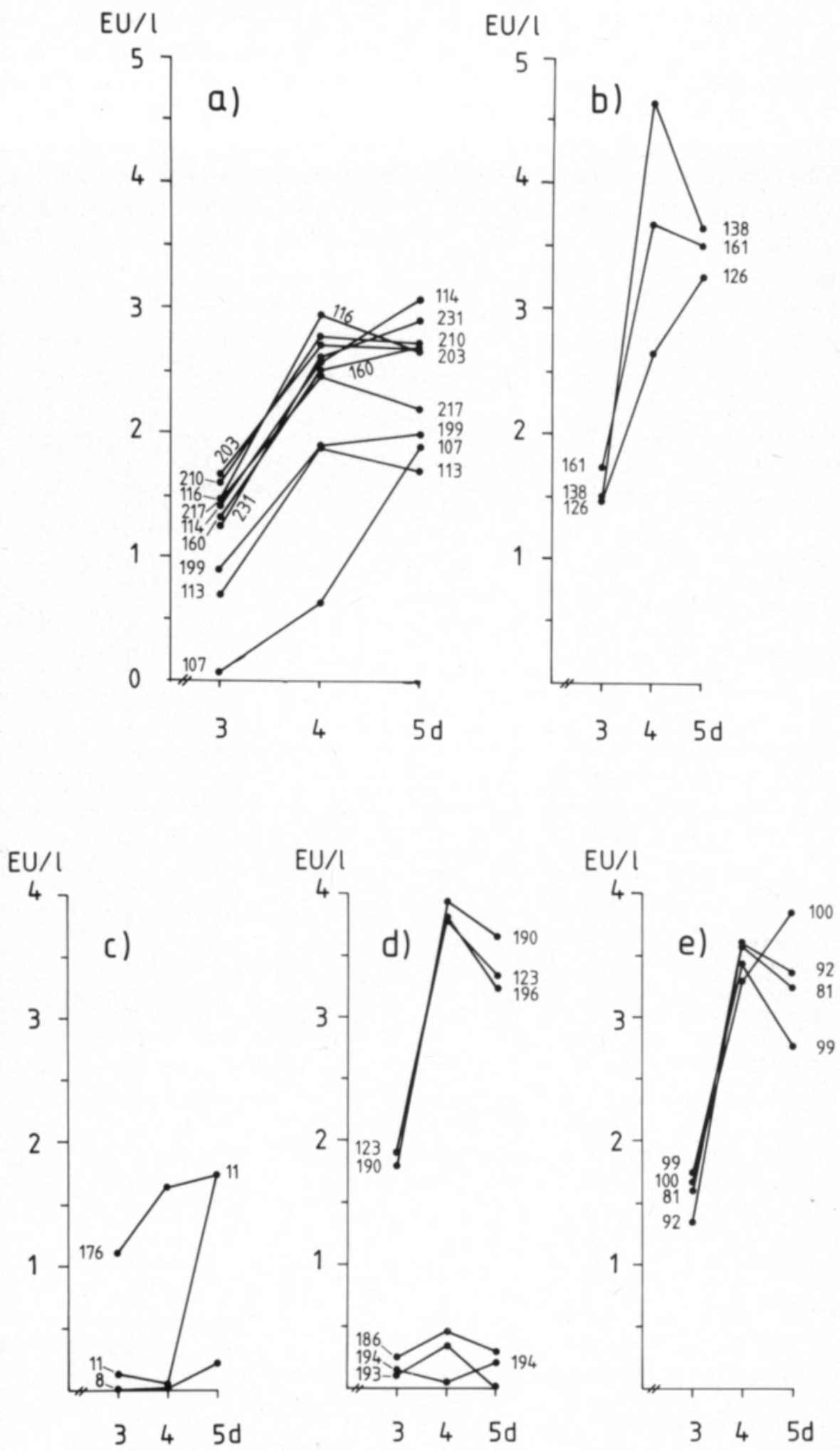

Fig. 1. Protease activity of actinomycetes (a) and other bacteria in uncultivated soil (b), arable soil (c), greenhouse peat (d) and pasture soil (e). 
these strains, 11 were actinomycetes originating chiefly from pasture soil (Fig. 1a). Many actinomycetes strains showed moderate protease activity. The bacterial strains from uncultivated soil showing high protease activity were all Bacillus cereus strains (Fig. 1b). Protease activity of strains originating from arable soil was relatively low (Fig. 1c). Two of these strains were bacilli (strain 8 Bacillus cereus var. mycoides, strain 11 Bacillus cereus) (Fig. 1c). Strains from peat represented both low and high protease activity (Fig. 1d). Three strains showed high protease activity: strain 123 was Bacillus subtilis, 190 and 196, not being identified, produced melanine and their utilization of glucose was oxidative. The four bacterial strains from pasture soil showing high protease activity were Bacillus coagulans strains, except strain 92 (Fig. 1e). Figure 1 shows that protease activity tended to be highest on the fourth day of protease production.

\section{Discussion}

In this study, pasture soil was superior to arable soil in terms of number of proteolytic bacteria, especially actinomycetes. This is in accordance with observations that protease activity is higher in pasture soil than in arable soil (LADD 1972) and availability of organic nitrogen is better in pasture soil than in tilled soil (HUNTJENS 1972). Because the proteolytic activity is concentrated in the surface layer of soil (Hoffmann and Teicher 1957), the disturbing effect of tillage on microbial flora may arise from the fact that surface soil is mixed into deeper layers. Increased proportions of actinomycetes in the microbial flora of grassland soil, as compared to that of tilled soil, have been reported also by WIERINGA (1958) and WoldENDORP (1963). Furthermore, according to SPEIR et al. (1982), the number of actinomycetes and other bacteria increases with pasture age.

Soil $\mathrm{pH}$ is an important factor in the maintenance of soil microbial flora. Generally, casein hydrolysing activity is low in acid soils
(AMBrož 1965). In this study, the number of proteolytic bacterial strains was greater in peat and pasture soil than in the other soils with lower $\mathrm{pH}$.

The abundance of proteolytic actinomycetes in pasture soil may partly be explained by the $\mathrm{pH}$ level of the soil (6.0) which was higher than the $\mathrm{pH}$ of the other soils examined. In greenhouse peat, however, typical actinomycetes were uncommon despite its high $\mathrm{pH}$ level (5.7). The low pH (3.5) of uncultivated muddy clay soil might explain the minute number of proteolytic actinomycetes and other bacteria as well. However, actinomycetes in general are known as active degraders of microbial biomass. Therefore, they may also reflect an rich microbial flora in pasture soil, as compared to the other soils investigated.

The richer proteolytic flora in peat and pasture soil, as compared to that of the other experimental soils, may also be related to the higher content of organic matter. This is supported by the observations of HOFFMANN and TeICHER (1975). They reported fivefold proteolytic activity in a peat soil $\left(\mathrm{pH}_{\mathrm{KCl}} 6.0\right)$ as compared to that in a sand soil $\left(\mathrm{pH}_{\mathrm{KCl}} 5.8\right)$. According to them, proteolytic activity in three sand soils with nearly the same $\mathrm{pH}$ (6.7-6.9) increased with increasing content of organic matter.

In this study, many strains with high protease activity were bacilli. The ability to utilize both inorganic and organic nitrogen might enhance the maintenance of bacilli in different soils (Mishustin and Mirsoeva 1968). The ability to form endospores may enable bacilli to survive in an inactive state in acid soils (Goodfellow et al. 1968, Holding et al. 1965).

Oxidase enzymes, especially peroxidases and phenoloxidases, play an important role in humification processes (SKUנINŠ 1967). Oxidase-producing bacteria have also been found in fertile soil (SUNDMAN 1970). Various organisms, e.g. common rhizosphere organisms like pseudomonads (EKLUND 1970), are included in oxidase producers. In this study, several strains isolated from peat and pasture 
soil were capable of producing oxidase enzymes.

Production of dark melanoid pigments resembling humic polymers is often found in cultures of fungi, actinomycetes and other bacteria (Von Plotho 1950, Küster 1952, 1955, Martin and Haider 1969, 1971, EKLund 1970, HunTJENS 1972). In this study, the production of melanoid pigments seemed to be associated chiefly with the strains isolated from pasture soil. Especially actinomycetes, which accounted for $70 \%$ of the proteolytic strains isolated from pasture soil, were melanoid producers. This is in accordance with the observation of Flaig and KutZnER (1960) that actinomycetes which produce melanoid pigments are more numerous in grassland soil than in tilled soil of the same type.

In soil, the phenolic compounds occur together with other oxidable compounds like proteins and carbohydrates, all involved in metabolic processes including formation of humic material. In the formation of humic material, metabolism of proteins and phenolic compounds are interrelated in such a way that amino acids released by the action of extracellular proteases react with phenols in the presence of phenoloxidases (e.g. HAIDER et al. 1965). Phenoloxidases also catalyze polymerization reactions of phenolic and humic compounds.

Presence of proteolytic actinomycetes in abundance in pasture soil may also be an indication of rich microbial biomass in the degradation of which actinomycetes hold a key position (Webley and Jones 1971). The results confirm from a certain microbial point of view the favourable influence of pastures (and leys in general) on the microbial activity in soil closely associated with mobilization of nitrogenous compounds and a restoring effect on the stable organic matter in soil.

\section{References}

Aмвrož, Z. 1965. O proteolytickén komplexy šlěpicim bilkoviny piidě. Rostlinná Vy̌roba 2: 161-170. Zusammenfassung: Über den proteolytischen, die Eiweisstoffe im Boden spaltenden Komplex (ref. Skujinš, J.J. 1967).

EkLund, E. 1970. Secondary effects of some pseudomonads in the rhizoplane of peat grown cucumber plants. Acta Agr. Scand. Suppl. 17: 1-57.

-, Backman, T. \& Gyllenberg, H.G. 1971. Extracellular proteases from soil actinomycetes I. Comparison with commercial Pronase B. Zbl. Bakt. Abt. II, 126: 725-734.

FlaiG, W. \& Kutzner, H.J. 1960. Beitrag zur Ökologie der Gattung Streptomyces Waksman et Henrici. Arch. Mikrobiol. 35: 207-228.

Goodfellow, M., Hıll, I.R. \& Gray, T.G.R. 1968. Bacteria in pine forest soil. The ecology of soil bacteria (eds. Gray, T.R.G. \& Parkinson, D.), p. 500-515. Liverpool.

Graham, E.R. 1948. Determination of soil organic matter by means of a photoelectric colorimeter. Soil Sci. 65: 181-183.

Haider, K., Frederick, L.R. \& Flaig, W. 1965. Reactions between amino acid compounds and phenols during oxidation. Plant and Soil 22: 49-64.

Hoffmann, G. \& Teicher, K. 1957. Das Enzymsystem unserer Kulturböden VII. Proteasen II. Z. Pflanzenernăhr. Düng. Bodenk. 77: 243-251.

Holding, A.J., Franklin, D.A. \& Watling, R. 1965. The microflora of peatpodzol transitions. J. Soil Sci. 16: $44-59$.

Hugh, R. \& Leifson, E. 1953. The taxonomic significance of fermentative versus oxidative metabolism of carbohydrates by various Gram negative bacteria. J. Bact. 66: $24-26$.

HUNTJENS, J.L.M. 1972. Immobilization and mineralization of nitrogen in pasture soil. Diss. Wageningen.

Jonsson, A.G. 1969. Proteases from fungi of the genera Alternaria and Entomophora. Diss. Uppsala.

KLINGE, K. 1960. Differential techniques and methods of isolation of Pseudomonas. J. Appl. Bact. 23: 442462.

KUSTER, E. 1952. Umwandlung von MikroorganismenFarbstoffen in Humusstoffe. Z. Pflanzenernähr. Düng. Bodenk. 57: 51-57.

- 1955. Humusbildung und Phenoloxydasen bei Streptomyceten. Z. Pflanzenernähr. Düng. Bodenk. 69: $137-142$.

LADD, J.N. 1972. Properties of proteolytic enzymes extracted from soil. Soil Biol. Biochem. 4: 227-237.

Martin, J.P. \& Haider, K. 1969. Phenolic polymers of Stachybotrys atra, Stachybotrys chartarum and Epicoccum nigrum in relation to humic acid formation. Soil Sci. 107: 260-270.

- \& HAIDER, K. 1971. Microbial activity in relation to 
soil humus formation. Soil Sci. 111: 54-63.

-, Richards, S.J. \& Haider, K. 1967. Properties and decomposition and binding action of whumic acid" synthetisized by Epicoccum nigrum. Proc. Soil Sci. Soc. Am. 31: 657-662.

Mishustin, E.N. \& Mirsoeva, V.A. 1968. Sporeforming bacteria in the soils of the USSR. The ecology of soil bacteria (eds. Gray, T.R.G. \& Parkinson D.), p. 458473. Liverpool.

Plotho, O. Von 1950. Die Humusbildung der Mikroorganismen. Z. Pflanzenernähr. Düng. Bodenk. 51: $212-224$.

RYTI, R. 1965. On the determination of soil $\mathrm{pH}$. J. Scient. Agric. Soc. Finl. 37: 51-60.

Shirling, E.B. \& Gottlieb, D. 1966. Methods for characterization of Streptomyces species. Int. J. Syst. Bact. 16: $313-340$.

Skerman, V.B.D. 1969. Abstracts of microbiological methods. 883 p. New York.

SkuJINS, J.J. 1967. Enzymes in soil. Soil Biochemistry 1 (eds. McLaren, A.D. \& Peterson, G.H.), p. 371-414.
New York.

Speir, T.W., Ross, D.J., Orchard, V.A., Cairns, A. \& PAnsier, E.A. 1982. Biochemical and microbiological properties of a West Coast wet land soil at different stages of pasture development. New Zealand J. Sci. 25: $351-359$.

Sundman, V. 1970. Four bacterial soil populations characterized and compared by a factor analytical method. Can. J. Microbiol. 16: 455-464.

WEBLEY, D.M. \& JonES, D. 1971. Biological transformation of microbial residues in soil. Soil Biochemistry 2 (eds. McLaren, A.D. \& Skujinš, J.), p. 446-485. New York.

WIERINGA, K.T. 1958. The problems of standardization of methods in use in microbiological soil research. Neth. J. Agr. Sci. 6: 61-67.

WoldendoRP, J.W. 1963. The influence of living plants on denitrification. Diss. 100 p. Wageningen.

Ms received November 6, 1985

\section{SELOSTUS}

\section{Ekstrasellulaarisia proteaaseja tuottavat sädesienet ja muut bakteerit viljelysmaassa}

\author{
Raina Niskanen ${ }^{1}$ ja Eva Eklund ${ }^{2}$ \\ 1 Maanviljelyskemian laitos, Helsingin yliopisto, \\ 00710 Helsinki 71 \\ ${ }^{2}$ Mikrobiologian laitos, Helsingin yliopisto, \\ 00710 Helsinki 71
}

Ekstrasellulaariset proteaasit ovat entsyymejä, jotka maassa osallistuvat typellisten orgaanisten jätteiden hajotukseen. Proteaaseja tuottavan mikrobiston koostumus ja runsaus riippuu ympäristötekijöistä kuten kosteudesta, lämpötilasta, ilmavuudesta, happamuudesta ja orgaanisen aineksen määrästă ja laadusta. Viljelytoimenpiteiden kuten muokkauksen avulla näihin ympäristőtekijöihin voidaan vaikuttaa. Tarkoituksena oli tutkia proteolyyttisten bakteerien määräă, laatua ja fysiologisia ominaisuuksia laidunmaassa ja sảănnöllisesti muokatussa peltomaassa. Lisäksi koemaina olivat orgaanista maata edustava kasvuturve ja viljelemätön hapan liejusavi. Koemaista eristetyistä 240 bakteerikannasta 68 oli proteolyyttistä. Eniten proteolyyttisiä kantoja eristettiin laidunmaasta, jossa näistă kannoista $70 \%$ oli sădesieniä. Myős turpeesta eristettiin runsaasti proteolyyttisiä bakteerikantoja, joiden joukossa ei kuitenkaan juuri ollut tyypillisiă sădesieniä. Useat kannat, joiden proteaasiaktiivisuus oli voimakas, osoittautuivat fermentatiivisiksi bacilluksiksi. Laitumen ja turpeen bakteerikannoille oli tavallista kyky muodostaa oksidaasientsyymejä, joilla on merkitystä humifioitumisprosesseissa. Tutkituille proteolyyttisille sädesienille oli tyypillistă kyky tuottaa tummia melanoidipigmenttejä. 